\title{
Synthesis of Novel and Bio-vital Pyridine based Ternary Compounds: Multi-Spectral Characterization, Biological Examination, Molecular Docking and In-Silico ADMET Profile
}

\author{
S. Syed Ali Fathima, E. R. Nagarajan
}

\begin{abstract}
The novel bio-crucial ternary compounds were synthesized and characterized by several spectral techniques and other physicochemical analysis. From all the measurements, octahedral structure was proposed for all the synthesized compounds. Moreover, the synthesized compounds have driven for their biological outlook. The DNA synergy was achieved by $U V$-studies displayed that the prepared complexes may interact with nucleic acid through intercalated pathway. In addition, the antimicrobial analysis of synthesized compounds explicated the compounds were best antibiotics against selected microbes. The gel electrolysis study showed that the major DNA bifurcation activity of the complexes to separate the pUC 18 nucleic acid fragment. The in-vitro antiproliferative activity of the complexes is investigated on breast and liver tumour cell panel confirmed that the metal complexes have considerable metastatic tumour ability. The antioxidising report evident that the metal complexes carry the attractive talent to chase the radical correlated to ligand. The drug-like evaluations exposed that the mixed ligand complexes possess substantial drug-like efficiency based on Lipinski's set of laws. Ultimately, the docking simulations are validated to realize the binding mode of the ternary compounds with FGFR protein and $1 B N A$.
\end{abstract}

Keywords: Antibiotics, Biological outlook, Drug-like efficiency, mixed ligand complex.

\section{INTRODUCTION}

Cells, uncontrolled multiplication, have a known death syndrome without appropriate medication until date. Recent medicine has produced long-term side effects for patients and instigates immediate requirements for patients and controls side effects. It is easy to prepare and inspect inorganic compounds with biochemically important ligands because some metal ions operate in various life schemes and the process of naturally happening compounds in this process is active. Copper together with $\mathrm{Mg}, \mathrm{Ca}, \mathrm{Fe}, \mathrm{Zn}, \mathrm{Cr}, \mathrm{V}$ and $\mathrm{Mn}$ are necessary metals which exhibit huge metabolic action while coupled with certain metalloprotein complexes involving in transfer of oxygen, electron transport or the ion storage that have formed immense eagerness in the study of metal containing complexes [1,2].

Schiff bases serve as an crucial place in material chemistry. Owing to their simplicity in synthesis, unique properties, clinical, biochemical and industrial utilizations, serious attention has been raised in the study of the compounds in recent years. Advances in bioinorganic chemistry have increased the focus on metal compounds as it is known that these complexes may act as models for many biological significant organisms [3-7].

Several investigations have been carried out where their deep bioactivity has been established to broaden the scope of investigations into the coordinating behaviour of various donor ligands [8-11], including Schiff sites toward organometallics. Metal-based drugs disturb natural cellular procedures such as mitosis and meosis gene expression and toxicity[12-15].

Most of the clinically verified chemotherapeutical medicines bound with DNA either covalent or non-covalent via diverse binding modes. [16-18]. In this research, the synthesis, characterization, DNA synergy, antimicrobial, antioxidant, cytotoxic studies, in-silico ADMET prediction and molecular docking simulations of 1,10-phenanthroline (phen) based novel ternary compounds are described.

\section{EXPERIMENTAL}

\section{A. Synthesis of ternary complexes}

The novel metal complexes of the type $\left[\mathrm{ML}_{1}(\mathrm{phen})_{2}\right] \mathrm{Cl}$ in 1:1:2 [Metal: Ligand: Phen] molar ratio were prepared by using previously reported Schiff base ligand by us [19]. ternary compounds was shown in Scheme 1. of Research and Education, Krishnankoil-626126, Tamil Nadu, India. Email:msm.syedali@gmail.com

*E. R. Nagarajan, Department of Chemistry, Kalasalingam Academy of Research and Education, Krishnankoil-626126, Tamil Nadu, India. Email: nagarajanklu@gmail.com 
<smiles></smiles>

Schiff base ligand
$\mathrm{MCL}_{2}$

Metal chloride

1

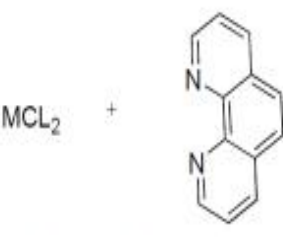

1,10-phenanthroline
Sonicated for $6 \mathrm{~h}$

Reflux for $24 \mathrm{~h} /$ Ethano

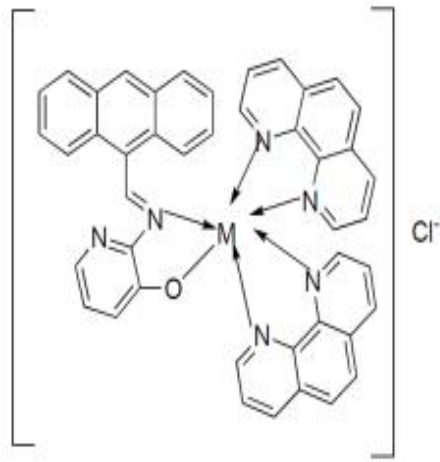

Mixed ligand complex

Where $\mathrm{M}=\mathrm{Cu}(\mathrm{II}), \mathrm{Co}(\mathrm{II}), \mathrm{Ni}(\mathrm{II})$ and $\mathrm{Zn}(\mathrm{II})$

Scheme 1. Synthesis of mixed ligand complexes.

\section{RESULTS AND DISCUSSION}

\section{A. Electronic spectra}

Ultra violet spectra provide the hopeful information on the structure of ligand in the metal compounds. Metal compounds display a one more band of $\mathrm{d}-\mathrm{d}$ band and this peak is utilized to identify the structure of the metal compounds [20]. Copper-compound displayed the d-d peak at $622 \mathrm{~nm}$, which is assigned ${ }^{2} \mathrm{Eg} \rightarrow{ }^{2} \mathrm{~T}_{2} \mathrm{~g}$. This $\mathrm{d}-\mathrm{d}$ transition and magnetic moment value $1.81 \mathrm{BM}$ which is highly supported the octahedral structure for this compound [21]. Co(II) compound produces a d-d band at $628 \mathrm{~nm}$ and this is a result of the octahedral geometry of the ${ }^{4} \mathrm{~T}_{1} \mathrm{~g}(\mathrm{~F}){ }^{4} \mathrm{~T}_{2} \mathrm{~g}(\mathrm{~F})$ transition. This is suggested by the magnetic moment of $4.68 \mathrm{BM}$. The $\mathrm{Ni}$ (II) complex forms the d-d band at $637 \mathrm{~nm}$, which is assigned the ${ }^{3} \mathrm{~A}_{2} \mathrm{~g}(\mathrm{~F}) \rightarrow{ }^{3} \mathrm{~T}^{1} \mathrm{~g}(\mathrm{~F})$ exchange and represents the octahedral geometry. It has the magnetic moment value 3.36 B.M. Zn(II) compound does not display a d-d peak since it has a completely filled $\mathrm{d}^{10}$ system and INCT peak. Instead, octahedral structure is proposed for the $\mathrm{Zn}$ (II) complex depending on its physical spectral analysis. The electronic spectra of the complexes are represented in Figs. 1 and 2.

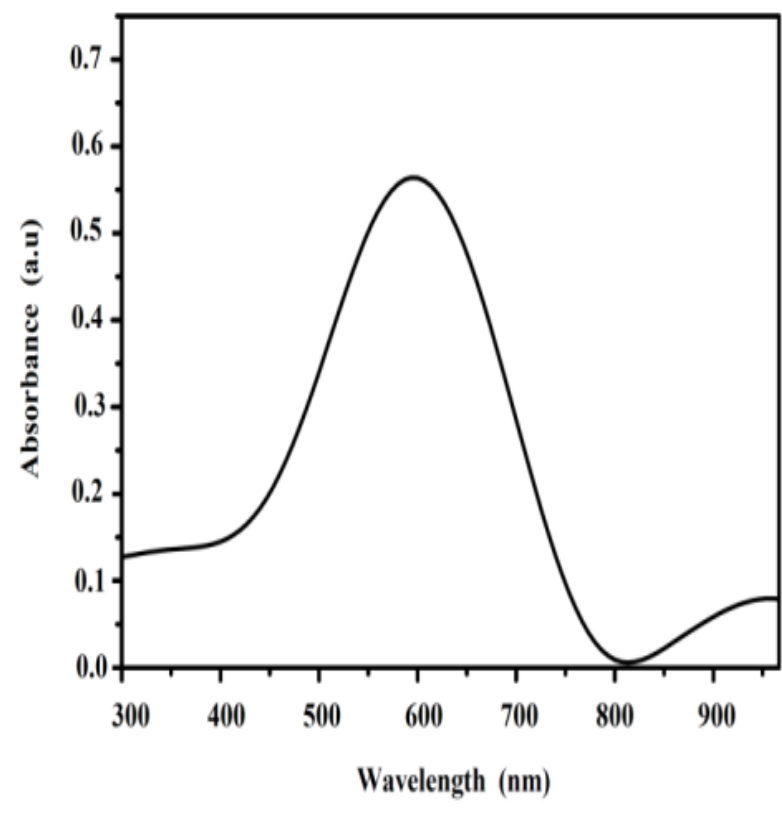

Fig. 1. Electronic spectrum of $\mathrm{Cu}(\mathrm{II})$ complex.

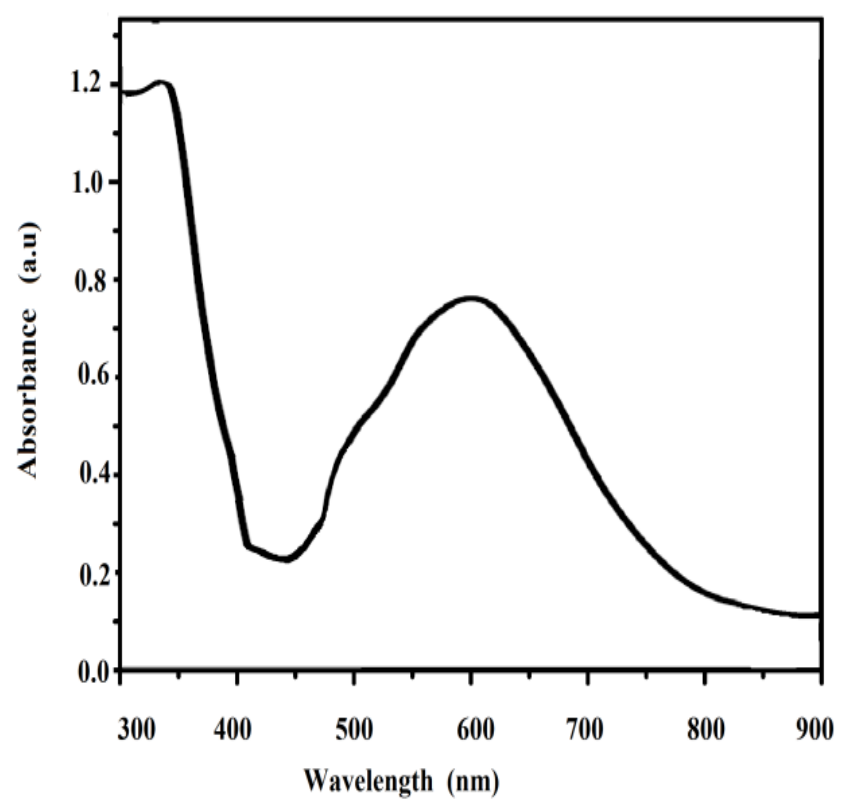

Fig. 2. Electronic spectrum of $\mathrm{Co}$ (II) complex.

\section{B. FT-IR spectra}

Infrared spectrum provides the detail of studying the interaction of the Schiff base ligand linked to the centre metal ion in coordination complexes. The strong band observed around $1570-1596 \mathrm{~cm}^{-1}$ in the metal compounds signifying that the chelation of $\mathrm{CH}=\mathrm{N}$ atom to the metal [22]. The double peaks are aroused in the less wave number range 420 $445 \mathrm{~cm}^{-1}$ and $530-545 \mathrm{~cm}^{-1}$ are designated as $v(\mathrm{M}-\mathrm{N})$ and $v(\mathrm{M}-\mathrm{O})$ stretching respectively recommending the involvement of $\mathrm{N}$ atom of $\mathrm{CH}=\mathrm{N}$ with metal ion while complexation. The FT-IR spectrum of synthesized complexes $\mathrm{Cu}(\mathrm{II})$ and $\mathrm{Ni}(\mathrm{II})$ is represented in Figs. 3. 


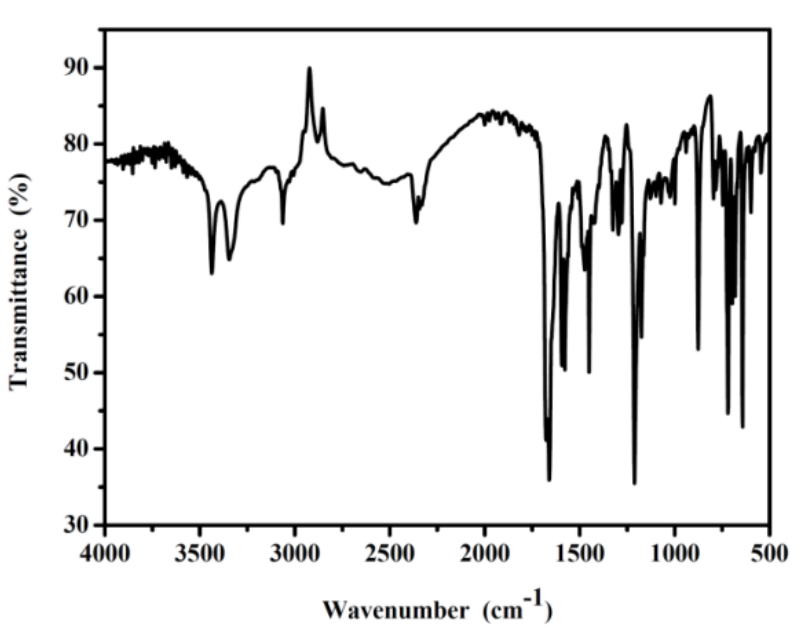

Fig. 3. FT-IR spectrum of $\mathrm{Cu}(\mathrm{II})$ complex.

\section{C. ${ }^{1}$ H NMR}

The NMR spectrum of Zinc(II) compound was correlated with free Schiff base. The peak due to aromatic proton appears around 7.31-8.6 ppm. The signals owing to the azomethine proton $(\mathrm{CH}=\mathrm{N})$ which is deviated to $8.88 \mathrm{ppm}$ in ternary complexes, which explained the complexation of $\mathrm{CH}=\mathrm{N}$ group to $\mathrm{Zn}(\mathrm{II})$. The signal due to $-\mathrm{OH}$ group was totally missing, which suggested that the removal of proton from-OH group and coordinated with metal ion. The ${ }^{1} \mathrm{HNMR}$ image of the complexes is portrayed in Fig. 4.

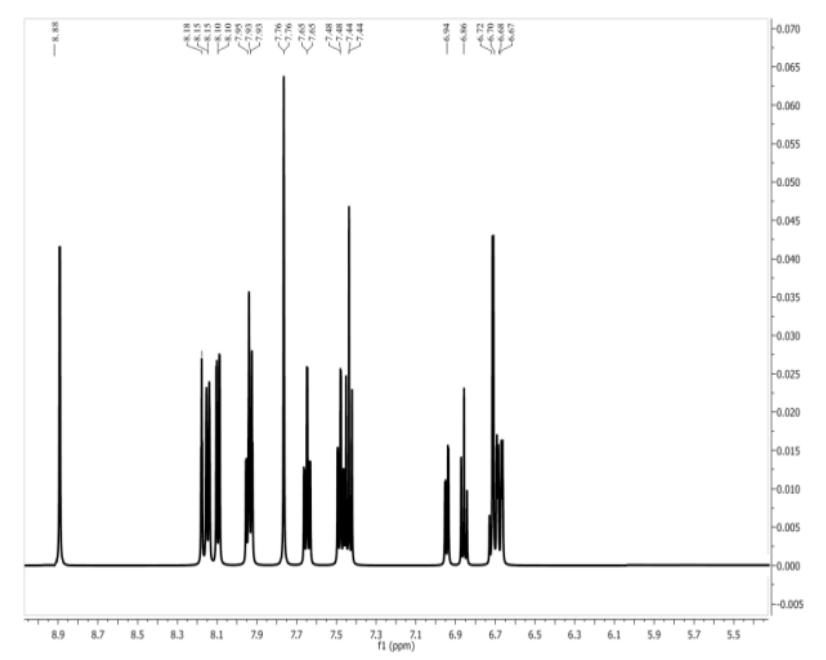

Fig. 4. ${ }^{1}$ HNMR spectrum of $\mathrm{Zn}$ (II) complex.

\section{D. ${ }^{13}$ C NMR}

The ${ }^{13} \mathrm{C}$ NMR image of the compound (Fig. 5) produces the aromatic protons around 120.00-135.08 ppm. The azomethine group gets moved to $158.07 \mathrm{ppm}$, which is strongly supported the chelation of this group to the metal. The signal owing to hydroxyl group was moved out and the fresh peaks awaken for (-C-O) group at $165.82 \mathrm{ppm}$ which signifies the removal of a proton from hydroxyl group and formation of metal oxygen bond during complexation [23].

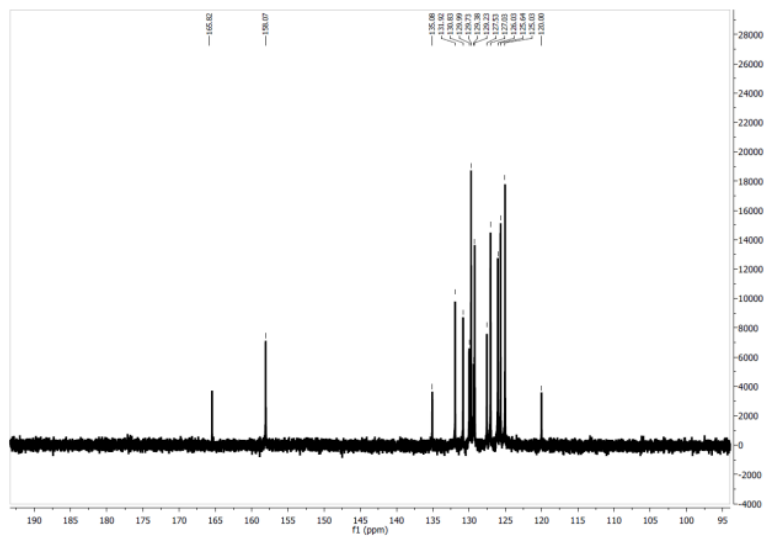

Fig. 5. ${ }^{13} \mathrm{C}$ NMR spectrum of $\mathrm{Zn}(\mathrm{II})$ complex.

\section{E. EPR SPECTRA}

EPR spectral parameters of copper complex, (2.32)> $\mathrm{g}_{\perp}$ (2.10); $\mathrm{A}_{\|}$(168) which indicates a octahedral geometry [26].

According to previous reports, the value of $\mathrm{G}>4.0$, local tetragonal axes exist in the parallel arrangement or slightly misplaced. In the case of $\mathrm{G}<4.0$ considerable exchange coupling interaction leads to significant deviation from regular geometry. For the synthesized complexes, the values of $\mathrm{g}_{\|} / \mathrm{A}_{\|}$are 138 which is enlisted in Table- I, which signify that the $\mathrm{Cu}$ compound has an octahedral configuration with gentle variation.

Table- I: EPR spectrum parameter of metal complex

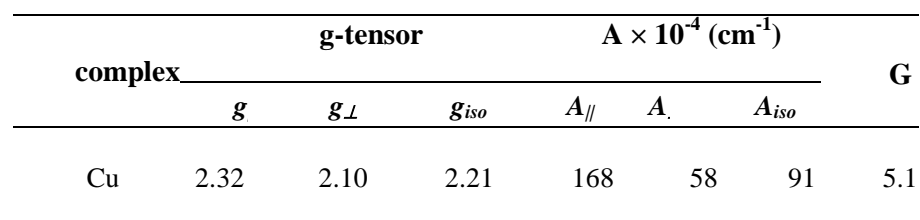

\section{BIOLOGICAL STUDIES}

\section{A. DNA binding experiments}

The interaction with metal compounds has potent approaches for the development of anti-neoplastic medicines. UV measurement is a most believable assessment for predicting the synergy of metal with nucleic acid. The binding among the compounds and nucleic acid are analyzed by this experiment and maintaining the alterations in absorbance which leads to alter in the frequency. This titration is achieved at a predetermined concentration of metal compounds with adding up of calf thymus DNA creates to find out the interaction approach accomplished among the metal compounds and nucleic acid.

The spectrum of the metal complexes, Copper and Nickel, with or without nucleic acid are laid out in Figs. 6 and 7. The slight changes in absorption value make a reallocate in the absorption (nm) [26]. 
Synthesis of Novel and Bio-vital Pyridine based Ternary Compounds: Multi-Spectral Characterization, Biological Examination, Molecular Docking and In-Silico ADMET Profile

The spectrum of all the compounds signified that the more intense absorption band in the region of 333-360 $\mathrm{nm}$. The serious accumulation of nucleic acid to the compounds developed major hypsochromism in the range of 9 to $15 \%$, which can be ascribed to the aptitude of compounds to loosen the helical configuration of nucleic acid and linked among the base pairs. This analysis was reworked till no alteration in the wavelength, recommending the stacking plethora.

Therefore, the reports procured from the titration suggest that the efficient binding of compounds with nucleic acid by the intercalated pathway and promote hypochromic effect. DNA binding parameters of the synthesized complexes are enlisted in Table-II.

Table-II: DNA binding study parameters of metal complexes

\begin{tabular}{|c|c|c|c|c|c|}
\hline \multirow[b]{2}{*}{ Complex } & \multicolumn{2}{|c|}{$\lambda \max$} & \multirow[b]{2}{*}{$\begin{array}{l}\Delta \lambda \\
(n m)\end{array}$} & \multirow[b]{2}{*}{${ }^{a} \mathrm{H} \%$} & \multirow[b]{2}{*}{$\begin{array}{r}K_{b} \times 10 \\
\left(M^{-1}\right)\end{array}$} \\
\hline & $\overline{\text { Free }}$ & $\begin{array}{l}\text { Bou } \\
\text { nd }\end{array}$ & & & \\
\hline $\mathrm{Cu}(\mathrm{II})$ & 338 & 345 & 7 & 16.7 & 9.2 \\
\hline $\mathrm{Co}(\mathrm{II})$ & 343 & 350 & 7 & 15.5 & 8.3 \\
\hline $\mathrm{Ni}(\mathrm{II})$ & 346 & 354 & 8 & 14.5 & 7.6 \\
\hline $\mathrm{Zn}(\mathrm{II})$ & 352 & 359 & 7 & 13.1 & 6.4 \\
\hline
\end{tabular}

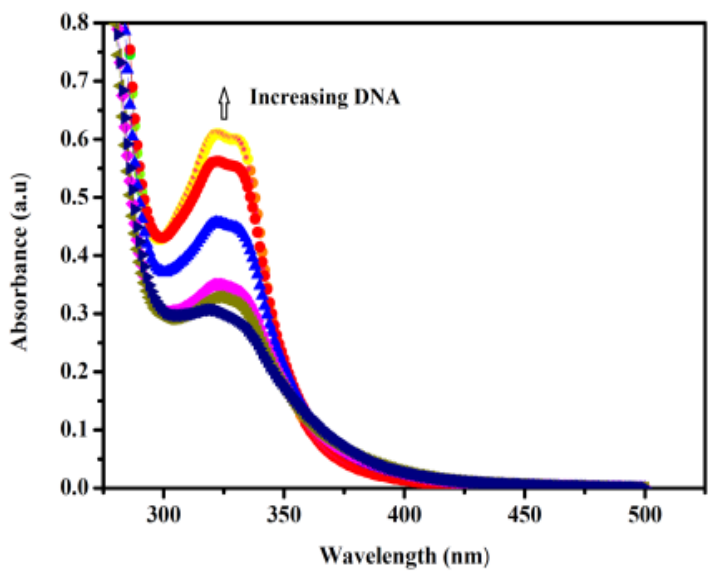

Fig. 6. DNA binding study of $\mathrm{Cu}$ (II) complex.

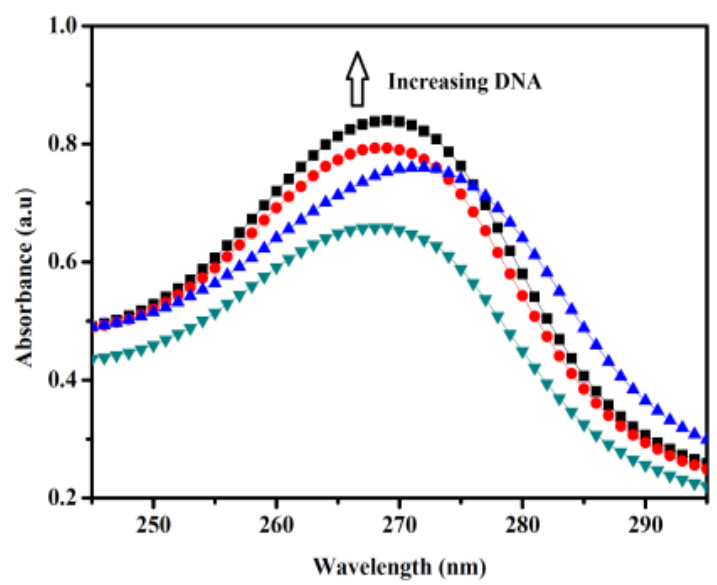

Fig. 7. DNA binding study of Zn(II) complex.

\section{B. DNA schism}

Deoxyribonucleic acid is the most competent internal constituent for various analysis, which is primarily on the efficacy of metal compounds to vivify the DNA endonuclease type cleavage. It is well-known that nucleic acid schism is glowing back by reconstruction of the SC type (type I) of pUC 18 DNA and converts NC (type II) and linear type (type III) which is shown in Fig. 8. In the absence of $\mathrm{H}_{2} \mathrm{O}_{2}$, no action has been portrayed to control DNA (Figure 8, Lane Control) This research designates that nucleic acid modifies its configuration because of the intercommunication of the metal compounds. This obviously mentions that the DNA schism action exists via the non-covalent contact of the co-ligand and develops free radical (ROS) and so the metal compounds contain superior efficiency than free Schiff base.

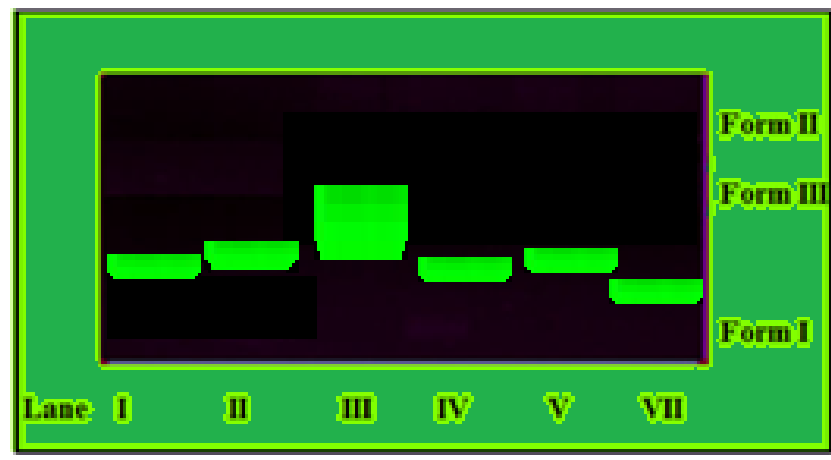

Fig. 8. DNA cleavage activity of synthesized compounds.

\section{Antimicrobial activity}

Bacterial strains can do battled against antibiotics via natural metabolic changes. In the current research, the metal compounds were investigated for the antimicrobial efficacy.

This is essential to the branch of clinical and pharmaceutical sectors. The data demonstrate that pathogens that connected $\mathrm{N}$ and $\mathrm{O}$ elements with metal ion boost the hindrance of enzyme formation in pathogens [27]. The metal compounds have exposed better screening talent related to the ligand since the coordinating ability of ligand with metal ion on the natural cell process. It is explained on the source of chelation concept. The screening studies of bacteria and fungi of the metal complexes is represented in Figs. 9 and 10.
Published By:

Blue Eyes Intelligence Engineering \& Sciences Publication 


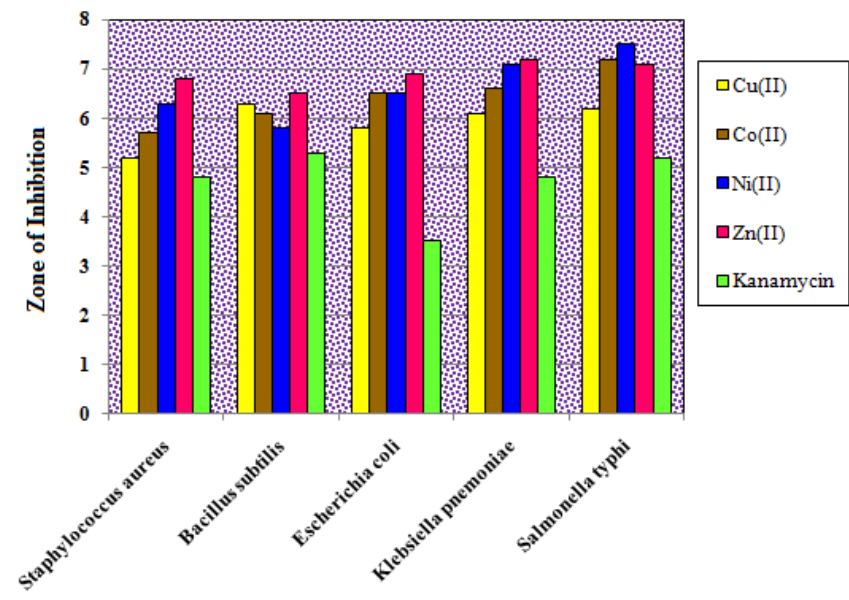

Fig. 9. Antibacterial activity of synthesized complexes.

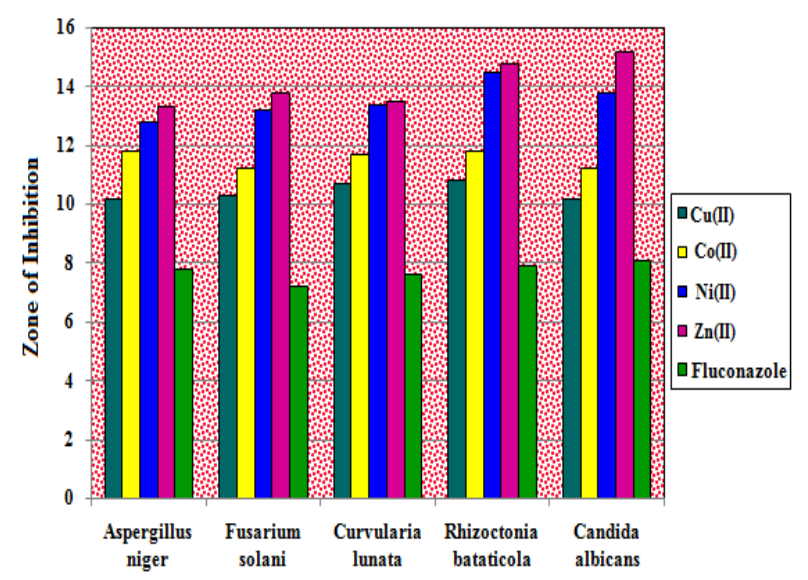

Fig. 10. Antifungal activity of complexes.

\section{In-vitro anticancer activity}

The hopeful results acquired from the screening studies, confident us to predict the antitumour action using MTT assay. Cisplatin is employed as the standard. Moreover, the activity of the compounds is fewer on the ordinary panel and particularly the synthesized compounds focus to kill on tumour cell lines. From the outputs, it is well-known that the Copper compound shows good antitumour action which is higher than other compounds. The antitumor action of the complexes is enclosed in Fig. 11.

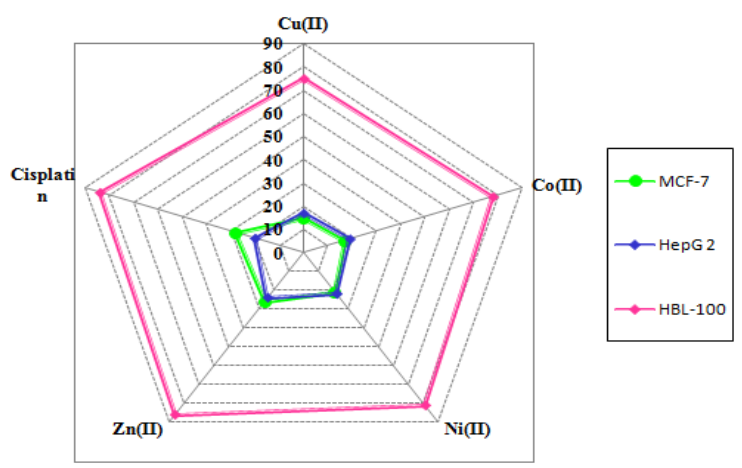

Fig. 11. Anticancer activity of synthesized compounds.

\section{E. Antioxidant activity}

The experiment was conducted by DPPH assay for exploring the antioxidant activity of complexes in various concentration levels $(10-40 \mu \mathrm{g} / \mathrm{mL})$ using standard ascorbic acid Metal compounds display better scavenging activity correlated to the ligand which is approximately the same as scavenging activity of ascorbic acid. Conversely, the scavenging ability enhances upon coordination and maximizes the aptitude to exude the living beings against some health issues. The scavenging activity of metal compounds is portrayed in Fig. 12 and data are shown in Table-III.

Table III. Radical scavenging property of metal complexes

\begin{tabular}{cccccc}
\hline $\begin{array}{c}\text { Concentration } \\
\boldsymbol{\mu} \mathbf{g} / \mathbf{m L}\end{array}$ & $\mathbf{C u}(\mathbf{I I})$ & $\mathbf{C o}(\mathbf{I I})$ & $\mathbf{N i}(\mathbf{I I})$ & $\mathbf{Z n}(\mathbf{I I})$ & $\begin{array}{c}\text { Vitamin } \\
-\mathbf{C}\end{array}$ \\
\hline 10 & 75.45 & 63.39 & 53.12 & 32.16 & 81.70 \\
20 & 81.61 & 53.81 & 76.12 & 87.05 & 90.04 \\
30 & 86.12 & 77.53 & 64.31 & 90.03 & 89.10 \\
40 & 94.12 & 82.13 & 86.12 & 87.99 & 93.11 \\
\hline
\end{tabular}

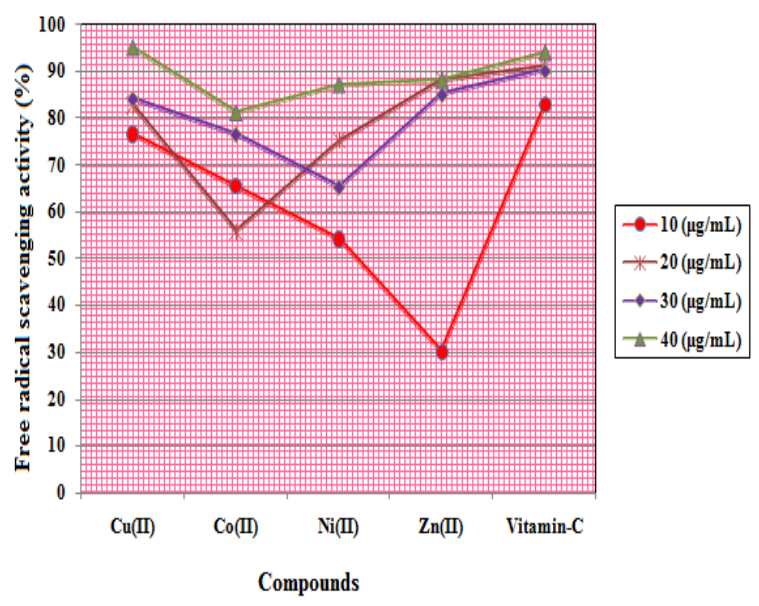

Fig. 12. Antioxidant activity of synthesized complexes.

\section{COMPUTATIONAL STUDIES}

\section{A. Drug-like evaluation}

Simulation offers a low-cost and fast approach to calculate the drug-like nature of molecules. SwissADME software are used to calculate their bioactivity values. This is employed to calculate the drug-likeness property of the compounds focused on the regulation of Lipinski.

- $\log$ P: This is a factor to verify the solubility character of the prepared compounds, which influence on the penetrability of the molecule throughout the metabolism of living beings.

- In the current work, Mi log P scores for the prepared complexes are lesser than five, it implies that the molecules which possess considerable pervious aptitude during metabolic pathway.

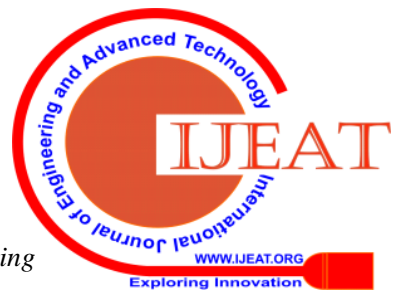


- Molecular weight: The molecular weight of the prepared compounds is more than 500. By Lipinski's law, the complexes have moderate capability.

- Topological molecular polar surface area (TPSA): This is a general analysis factor on the $\mathrm{H}$-bond $(\mathrm{O}$ and $\mathrm{N}$ Atom counts) essential to recognize cell-penetrating skill. TPSA is measured by adding $\mathrm{O}, \mathrm{N}$ and attached $\mathrm{H}$ in prepared compounds. TPSA value $86.04 \AA^{2}$ (below $140 \AA^{2}$ ), which indicated that synthesized compounds have excellent transportation ability and may be in favour of oral management.

- Rotatable bonds: According to this rule, while the rotatable bond increases, the compounds become longer and more conveniently fit in the precise active centres. The counting of this parameter for synthesized metal chelates are three. In the current investigation, the data evidently designated that the synthesized compounds possess suitable aptitude to interact with the biological system powerfully.

- Bioactivity score: The drug should be entrenched with a natural entities. For this research, metal compounds have a value of 0.17 . According to Lipinski's rule, the compounds that have bioactivity scores greater than zero which implies that they have the best drug-like action.

- Toxicity assessment: Mutagenic activity (cancer) diagnosed in AdmetSAR software. The evaluation of this scale as the main goal in the detection of toxic-free drugs. From the computation all the compounds do not have any toxic manners.

\section{B. Docking simulations}

Docking simulation is employed to authenticate the synergy mode of receptors with synthesized complexes [28]. The available inhibitor of the fibroblast growth factor receptor (FGFR) with potential antineoplastic activity. This is using Autodock Vina software against protein FGFR inhibitor in Fig. 13. From the research, the free energy of the complexes are -245.61 Cu(II), -232.04 Co(II), -231.92 Ni(II)) and $-230.83 \mathrm{~kJ} / \mathrm{mol} \mathrm{Zn}(\mathrm{II})$. Docking simulations denote that metal complexes possess a higher binding force with protein rather than free ligand [19]. The docking with nucleic acid was achieved by the same software using receptor DNA (PDB ID: 1BNA). The free energy of synthesized compounds with 1BNA is $-210.44(\mathrm{~L}),-235.75 \mathrm{Cu}(\mathrm{II}), \quad-212.44 \mathrm{Co}(\mathrm{II})$, $-221.44 \mathrm{Ni}$ (II) and $-209.55 \mathrm{Zn}$ (II) kJ/mol. The result (Fig. 14) ensures that all the complexes were interconnected with base pairs via intercalated pathway.

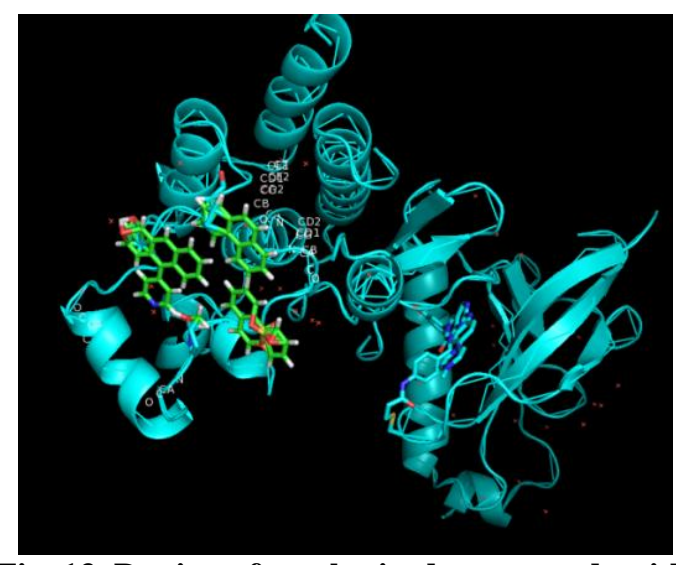

Fig. 13. Doping of synthesized compounds with FGFR receptor.

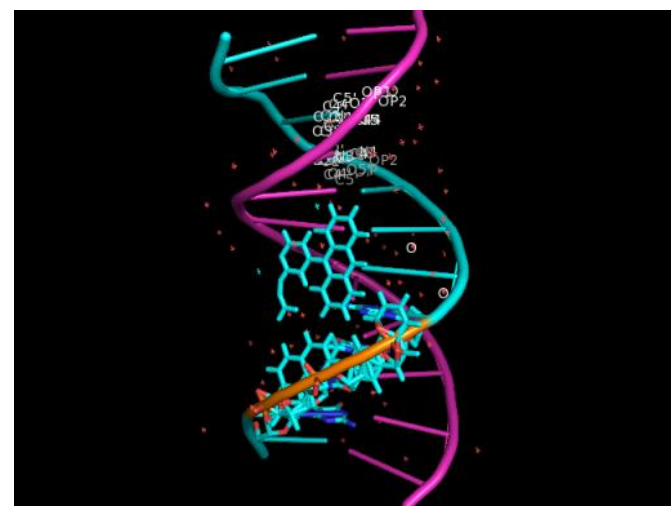

Fig. 14. Doping of synthesized compounds with 1BNA.

\section{CONCLUSION}

The novel bio-energetic ternary compounds were prepared and characterized by multispectral and biological studies. According to elemental and magnetic measurements, synthesized compounds espouse the octahedral geometry. All the compounds interact with calf thymus DNA via the intercalated stacking. The nuclease stimulation outputs explains that the prepared compounds were capable of cutting the nucleic acid filaments with activator. All the prepared complexes display the advanced antibiotic, antitumor and antioxidant activity correlated to the ligand. The significant biological function of ternary complexes was owing to the specific molecular shape of the complexes and properties for secondary ligands present in the coordination sphere. The prediction in-silico ADMET properties reveal that the prepared compounds possess outstanding drug-likeness behavior. Docking simulation has solved, which expressed the method of bonding with FGFR enzyme and 1BNA. Finally, the greatest reports from this study, if more tuned, it may have woken up in more efficient chemotherapeutics.

\section{ACKNOWLEDGMENT}

The author, S.SAF gratefully acknowledges the Kalasalingam Academy of Research and Education for offering research fellowship and necessary facilities. 


\section{REFERENCES}

1. R.N. Guna, J. M. Vyas, A. Ramkishan, Y. K. Agrawal, "Reviews in Anal. Chem, vol. 31, 2012, pp. 193-199.

2. A.A. Warra, Transition metal complexes and their application in drugs and cosmetics - A Review. J. Chem. Pharm. Res., vol. 3, 2011, pp. 951-958,

3. C. Jeon, Adsorption characteristics of copper ions using magnetically modified medicinal stones. J. Ind. Engg. Chem., vol. 17, 2011, pp. 321-324,

4. M. Montazerozohori, S. Zahedi, M. Esfahani, A. Naghiha, Some new cadmium complexes: Antibacterial/antifungal activity and thermal behavior, J. Ind. Engg. Chem., vol. 20, 2013, pp. 2463-2470.

5. S. Golbabapour, N. S. Gwaram, P. Hassandarvish, M. Hajrezaie, B. Kamalidehghan, Abdulla, M. A., Ali, H. M., Hadi, H. A., Majid, N.A., Gastroprotection Studies of Schiff Base Zinc (II) Derivative Complex against Acute Superficial Hemorrhagic Mucosal Lesions in Rats, Plos One, vol. 8, 2013,pp. 75036-75041.

6. C.J. Dhanaraj, M. S. Nair, Metal complexes as therapeutic substitute in tuberculosis treatment, BMC Infectious Diseases, vol. 14, 2014 pp. 29-35.

7. L.S. Redgrave, S. B. Sutton, M. A. Webber, L.J.V. Piddock, Fluoroquinolone resistance: Mechanisms, impact on bacteria and role in evolutionary success, Trends in Microbiology, vol. 22, 2014, pp. 438-445,

8. L.A. Soares, J.C. O. Sardi, F. P. Gullo, N. S. Pitangui, L. Scorzoni, F.S Leite, M.S. M. Giannini, A.M.F. Almeida, Anti dermatophytic therapy-Prospects for the discovery of new drugs from natural products, Braz. J. Microbiol., vol. 44, 2013, pp.1035-1041.

9. F. Islahudin, S. M. Tindall, I. R. Mellor, K. Swift, H. E. M. Christensen, K. F. Fone, R. J. Pleass, K. N. Ting, S. V. Avery, The antimalarial drug quinine interferes with serotonin biosynthesis and action, Scientific Reports, vol. 4, 2013, pp. 1-7.

10. P. Maury, A. Rollin, Galinier M, Juilliere Y, Role of digoxin in controlling the ventricular rate during a trial fibrillation: A systematic review and a rethinking, Research Reports in Clinical Cardiology, vol. 5, 2014, pp. 93-101.

11. A. Chraibi, S. Renauld, PPAR $\gamma$-Induced Stimulation of Amiloride-Sensitive Sodium Current in Renal Collecting Duct Principal Cells is serum and insulin Dependent, Cell Physiol Biochem., vol. 33, 2014, pp 581-593.

12. M. Grazul, E. Budzisz, Biological activity of metal ions complexes of chromones, coumarins and flavones, Coordination Chemistry Reviews, vol. 253, 2009, pp 2588-2598

13. Y. Ni, S. Du, S. Kokot, Interaction between quercetin-copper (II) complex and DNA with the use of the Neutral Red dye fluorophor probe, Analytica Chimica Acta, vol. 584, 2007, pp. 19-27.

14. A.M. Akbar, A.H. Mirza, J. H. Hjh A. Bakar P.V. Bernhardt, Preparation and structural characterization of nickel(II), cobalt(II), zinc(II) and tin(IV) complexes of the isatin Schiff bases of S-methyl and S- benzyldithiocarbazates, Polyhedron, vol. 30, 2011 pp. 556-564.

15. W. Rehman, S. Rehman, B. Muhammad, S.T. Shah, I. Tauseef, C.Y. Guo, Synthesis, characterization and antiinflammatory activity of some organotin(IV) complexes, Pol. J. Chem., vol. 83, 2009, pp. 2207-2213.

16. P.C.A. Bruijnincx, P.J. Sadler, New trends for metal complexes with anticancer activity, Curr. Opin. Chem Biol. vol. 12, 2008, pp 197- 206.

17. D.R. Boer, A. Canals, M. Coll, DNA-binding drugs caught in action: The latest 3D pictures of drug-DNA complexes, Dalton Trans., vol. 2009, pp. 399-414.

18. J.P. Sauvage, J.P. Collin, J.C. Chambron, S. Guillerez, C. Coudret, V. Balzani, F. Barigelletti, L.D. Cola, L. Flamigni, Ruthenium(II) and osmium(II) bis(terpyridine) complexes in covalently-linked multicomponent systems: Synthesis, electrochemical behaviour, absorption spectra, and photochemical and photophysical properties, Chem. vol. 94, 1994, pp. 993-1019.

19. S. Syed Ali Fathima, M. Mohamed Sahul Meeran, E.R. Nagarajan, Synthesis of novel(E)-2-((anthracen-9-ylmethylene)amino)pyridin-3-ol and its transition metal complexes: Multispectral characterization, biological evaluation and computational studies, J. Mol. Liq. vol. 279 , 2019, pp. 177-183.

20. A.B.P. Lever, Studies in physical and theoretical chemistry. Inorganic Electronic Spectroscopy Elsevier Amsterdam 33.

21. F.A. Cotton, G. Wilkinson, Advanced Inorganic Chemistry, Wiley- Interscience, New York 1-1376, 1998.

22. M.C. Day, J. Selbin, Theoretical Inorganic Chemistry, Litton Edu Pub Inc., 1969.
23. D. Banerjea, Coordination Chemistry, Tata McGraw-Hill Pub New Delhi, 1998.

24. L. Cao, Q. Chen, X. Hou, H. S. Chen, H. Guan, Y. Ma,W. Peng, A. Xu, Synthesis, acute toxicities and antitumor effects of novel-9. substituted- $\beta$-carboline derivatives, Bioorg. Med. Chem., vol. 12, 2004, pp. 4613-4623.

25. A. Abebe, T. Hailemariam, Synthesis and assessment of antibacterial activities of ruthenium(III) mixed ligand complex containing 1,10-phenanthroline and guanine, Bioinorg. Chem. Appl., vol. 12, 2016 pp. 1-9.

26. A.O. Adeloye, P.A. Ajibade, Synthesis and characterization of a Ru(II) complex with functionalized phenanthroline ligands having single-double linked anthracenyl and 1-methoxy-1-buten-3-yne moieties, Molecules, vol. 15, 2010, pp 7570-7581.

27. T. Rosu, E. Pahontu, S. Pasculescu, R. Georgescu, N. Stanica, A. Curaj, A. Popescu,M. Leabu, Synthesis,characterization antibacterial and antiproliferative activity of novel $\mathrm{Cu}$ (II) and $\mathrm{Pd}(\mathrm{II})$ complexes with 2-hydroxy-8-R-tricyclo[7.3.1.0.(2,7)] tridecane-13-one thiosemica rbazone, Eur. J. Med. Chem., vol. 45, 2010 pp. 1627- 1634.

28. R.F. Brissos, E. Torrents, F. M. S. Mello, W.C. Pires, E. P. Silveira Lacerda, A.B. Caballero, A. Caubet, C. Massera, O. Roubeau, S.J. Teat, P. Gamez, Highly cytotoxic DNA interacting copper(II) coordination compounds, Metallomics, vol. 6, 2011, pp. 1853-1868.

\section{AUTHORS PROFILE}

S. Syed Ali Fathima pursuing Ph.D in the area of coordination compounds, biological application and computtational simulationns at Kalasalingam Academy of Research and Education, Krishnankoil, Tamil Nadu, India

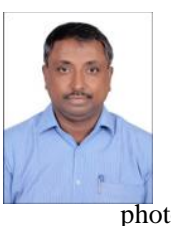

E. R. Nagarajan works as Associate Professor, Department of Chemistry, Kalasalingam Academy of Research and Education, Krishnankoil, Tamil Nadu, India. He received his Ph.D degree at Anna University, Chennai, India. With a research in the applications of polymeric materials, co-ordination compounds, photocatalysis and electrochemical applications. 